\title{
SISTEM PENDUKUNG KEPUTUSAN PENILAIAN KINERJA PEGAWAI UNTUK KENAIKAN JABATAN MENGGUNAKAN METODE SIMPLE MULTI ATTRIBUTE RETTING TECH (SMART)
}

\author{
Syahrin Syam Noor Berutu, Jufriadif Na'am, Sumijan \\ Universitas Putra Indonesia YPTK Padang, Indonesia \\ syahrin.berutu@gmail.com
}

\begin{abstract}
ABSTRAK
Pengambilan Keputusan dalam suatu Kantor sangatlah penting karena keputusan yang diambil oleh Pimpinan merupakan hasil pemikiran akhir yang harus dilaksanakan oleh Pegawai. Badan Pengelolaan Pajak dan Retribusi (BP2RD) Kota Medan merupakan Kantor yang ada di Jalan Jendral Besar H. Abdul Haris Nasution, dimana proses penilaian kenaikan jabatan Pegawainya meliputi Orientasi Pelayanan, Integritas, Komitmen, Disiplin, Kerjasama, Kehadiran. Menggunakan Metode Simple Multi Attribute Retting Tech ( SMART) dapat membantu dalam pengambilan keputusan untuk menentukan Kenaikan Jabatan Pegawai pada Kantor tersebut, Serta proses penilaian Pegawai lebih efisien sehingga Pimpinan dapat menentukan Kenaikan Jabatan Pegawainya dengan cepat. Dengan menggunakan Sistem Pendukung Keputusan yang memiliki Database, Data Pegawai dapat disimpan didalam Database. Sehingga apabila terjadi kesalahan dalam penginputan dapat diperbaiki tanpa harus menginput ulang data tersebut. Dengan adanya Sistem Penunjang Keputusan ini akan mengatasi permasalahan yang terjadi di Badan Pengelolaan Pajak dan Retribusi (BP2RD) Kota Medan, sehingga proses kenaikan Jabatan akan lebih cepat.

Primary Key : Sistem Pendukung Keputusan, Keputusan, Simple Multi Attribute Retting Tech ( SMART), Pegawai
\end{abstract}

\section{Pendahuluan}

Penilaian kinerja Pegawai adalah penilaian secara periodik pelaksanaan pekerjaan seorang Pegawai. Tujuan penilaian kinerja adalah untuk mengetahui keberhasilan atau ketidak berhasilan seorang Pegawai, dan untuk mengetahui kekurangan dan kelebihan yang dimiliki oleh Pegawai yang bersangkutan dalam melaksanakan tugasnya. Hasil penilaian kinerja digunakan sebagai bahan pertimbangan dalam pembinaan Pegawai, antara lain pengangkatan, kenaikan pangkat, pengangkatan dalam jabatan, pendidikan dan pelatihan, serta pemberian penghargaan. Penilaian kinerja Pegawai dilaksanakan berdasarkan Peraturan Pemerintah Nomor 10 Tahun 1979 tentang Penilaian Pelaksanaan Pekerjaan Pegawai Negeri Sipil.

Unsur-unsur yang dinilai dalam melaksanakan penilaian pelaksanaan pekerjaan adalah : kesetiaan, prestasi kerja, tanggung jawab, ketaatan, kejujuran, kerjasama, prakarsa dan kepemimpinan atau unjuk kerja (perfomance appraisal) seorang pegawai. Dilingkungan PNS dikenal dengan DP-3 (Daftar Penilaian Pelaksanaan Pekerjaan) yang diatur dalam PP 10 Tahun 1979. Cara menilai aspek kualitas dalam suatu pekerjaan /kegiatan adalah dengan mengacu pada parameter yang ada pada Peraturan Kepala BKN Nomor 1 Tahun 2013 pada halaman 20.

Sistem Pendukung Keputusan merupakan suatu sistem interaktif yang mendukung keputusan dalam proses pengambilan keputusan melalui alternatifalternatif yang diperoleh dari hasil pengolahan data, informasi dan rancangan model. Dalam perancangan sistem pendukung keputusan dibutuhkan sebuah metode yang diterapkan dalam perhitungan dimana sistem pendukung keputusan ini menggunakan Metode SMART. 
Metode SMART (Simple Multi Attribute Rating Technique) merupakan metode pengambilan keputusan multi atribut yang digunakan untuk mendukung pembuat dalam memilih antara beberapa alternatif. Setiap pembuat keputusan harus memilih sebuah alternatif yang sesuai dengan tujuan yang telah dirumuskan. Setiap alternatif terdiri dari sekumpulan atribut dan setiap atribut mempunyai nilai-nilai. Nilai ini di rata rata dengan skala tertentu.

Dari latar belakang diatas penulis merumuskan permasalahan dalam penelitian ini yaitu :

1. Bagaimana menentukan penilaian kinerja pegawai untuk kenaikan jabatan pada Badan Pengelolaan Pajak dan Retribusi Daerah Kota Medan dengan metode Simple Multi Attribute Retting Tech?

2. Bagaimana menerapkan metode Simple Multi Attribute Retting Tech (SMART)

3. Bagaimana merancang Sistem Pengambilan Keputusan untuk menentukan Kelayakan Kepada Pegawai untuk Pengajuan kepangkatan pada Badan Pengelolaan Pajak dan Retribusi Daerah Kota Medan?

\section{Tinjauan Literatur}

\subsection{Konsep yang mendasari dalam Sistem Pendukung Keputusan}

\section{Pengertian Sistem Pendukung Keputusan}

Menurut Bagas Setiyaki Wicaksono memberikan pengertian yang mencakup semua SPK mulai dari dasar sampai yang paling ideal. Turban mengatakan Sistem Pendukung Keputusan (SPK) tersebut adalah kemampuannya untuk menyelesaikan masalah-masalah yang tidak terstruktur. Sistem Pendukung Keputusan dimaksudkan untuk menjadi alat bantu pengambil keputusan dalam hal ini Premium untuk memperluas kapabilitas mereka, namun tidak menggantikan penilaian mereka (Universitas Pamulang : 2018).

\section{Metode Simple Multi Attribute Retting Tech (SMART)}

Metode Simple Multi Attribute Retting Tech (SMART) sering dikenal dengan istilah metode penjumlahan terbobot. Konsep dasar metode Simple Additive Weighting (SAW) adalah mencari penjulahan terbobot dari rating kinerj pada setiap alternative pada semua atribut (Rusito, 2017). langkah-langkah penyelesaian dari metode SAW (Rusito, 2017) sebagai berikut :

1. Menentukan jumlah kriteria

2. Memberikan skala prioritas atau bobot preferensi pada setiap kriteria kemudian dilakukan normalisasi bobot.

3. Memberikan nilai pada setiap kriteria untuk setiap alternatif.

4. Menghitung nilai utility untuk setiap kriteria.

5. Hitung nilai akhir masing-masing alternatif dan melakukan perangkingan. 


\section{Metodologi Penelitian}

Secara garis besar metodologi penelitian ini dapar dilihat pada gambar 3.1

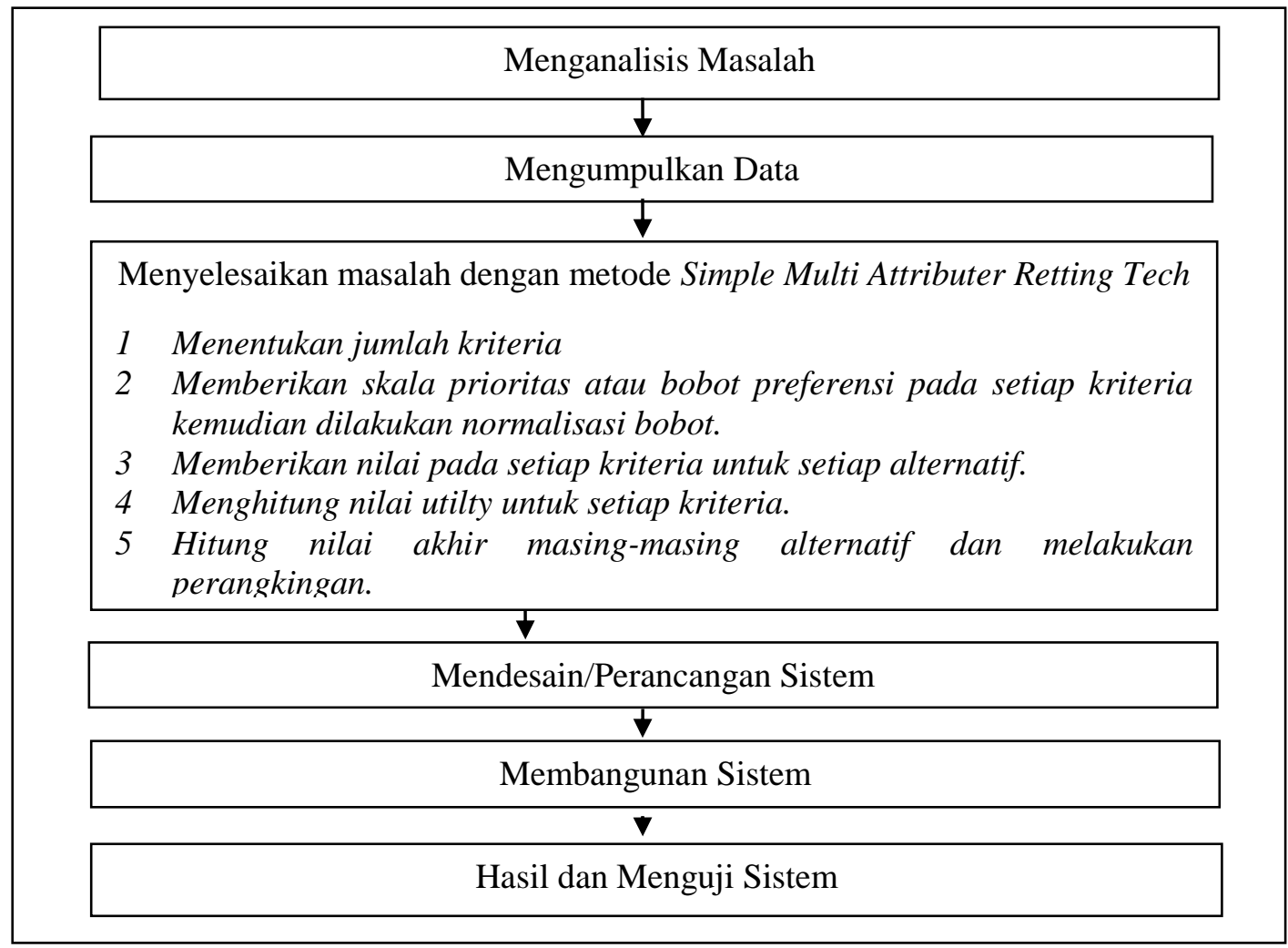

Gambar 3.1 Kerangka Alur Penelitian

\section{Hasil dan Pembahasan}

\subsection{Tahapan Analisa dan Perancangan}

Tahapan analisa sistem dan perancangan sangat dibutuhkan didalam sebuah penelitian untuk mempengaruhi kualitas dan kuantitas dari sistem. Dapat dilihat pada gambar 4. 1 berikut:

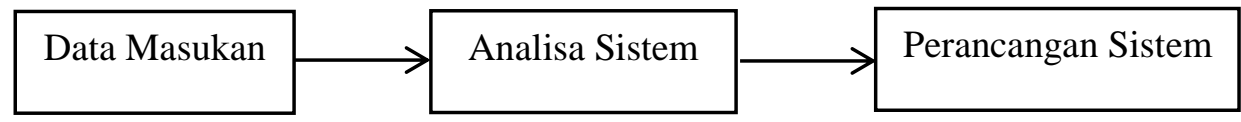

Gambar 4.1 Tahapan Analisa dan Perancangan

\subsection{Perhitungan Smart}

\subsubsection{Data Kriteria}

Dalam proses pembuatan Sistem Pendukung Keputusan untuk Pegawai disekitar Lingkungan Badan Pengelolaan Pajak dan Retribusi Kota Medan, maka ada beberapa data yang dijadikan pertimbangan dalam proses perancangan system tersebut. Data tersebut akan dijadikan kriteria dalam memilih Pegawai. 
Adapun kriteria-kriteria dalam pemilihan Pegawai adalah :

1. Orientas Pelayanan

2. Integritas

3. Kehadiran

4. Kerjasama

5. Komitmen

6. Disiplin

\subsubsection{Bobot Kriteria}

1. Menentukan jumlah kriteria

Berdasarkan data hasil penilaian yang telah di tetapkan dari Badan Pengelolaan Pajak dan Retribusi Daerah Kota Medan, kriteria yang menjadi point penilaian berjumlah 6 yaitu.
a. Orientas Pelayanan
b. Itegritas
c. Komitmen
d. Disiplin
e. Kerjasama
f. Kehadiran

2. Memberikan skala prioritas atau bobot preferensi pada setiap kriteria kemudian dilakukan normalisasi bobot.

Tabel 4.1 Tabel Nilai Bobot Kriteria

\begin{tabular}{|c|c|c|}
\hline NO & KRITERIA & BOBOT \\
\hline 1 & Orientas Pelayanan & 85 \\
\hline 2 & Itegritas & 78 \\
\hline 3 & Komitmen & 80 \\
\hline 4 & Disiplin & 85 \\
\hline 5 & Kerjasama & 75 \\
\hline 6 & Kehadiran & 80 \\
\hline
\end{tabular}

Normalisasi Bobot dilakukan dengan menggunakan rumus:

$$
N_{i}=\frac{W_{i}}{\sum W_{i}}
$$

Tabel 4.2 Tabel Normalisasi Nilai Bobot Kriteria

\begin{tabular}{|c|c|c|c|}
\hline NO & KRITERIA & BOBOT & Nil. Normalisasi \\
\hline 1 & Orientas Pelayanan & 85 & $85 / 483=0.18$ \\
\hline 2 & Itegritas & 78 & $78 / 483=0.16$ \\
\hline 3 & Komitmen & 80 & $80 / 483=0.17$ \\
\hline 4 & Disiplin & 85 & $85 / 483=0.18$ \\
\hline 5 & Kerjasama & 75 & $75 / 483=0.16$ \\
\hline 6 & Kehadiran & 80 & $80 / 483=0.17$ \\
\hline & Total & 483 & \\
\hline
\end{tabular}

3. Memberikan nilai pada setiap kriteria untuk setiap alternatif.

merupakan data penilaian bagi masing-masing pegawai yang akan digunakan dalam algoritma perhitungan metode SMART.

4. Menghitung nilai utility untuk setiap kriteria.

Untuk menghitung nilai Utility setiap alternatif maka digunakan rumus: 


$$
u_{i}\left(a_{i}\right)=100 \frac{\left(C_{\max }-C_{\text {out }}\right)}{\left(C_{\text {Max }}-C_{\min }\right)} \%
$$

Untuk perhitungan alternatif ke-1 yaitu Adi Tawarwan Damanik dengan penilaian 90;86;70;81;80;85.

Untuk nilai utility

$$
\begin{aligned}
& u_{1}\left(a_{1}\right)=100 \frac{(100-90)}{(100-0)} \%=10 \\
& u_{2}\left(a_{1}\right)=100 \frac{(100-86)}{(100-0)} \%=14 \\
& u_{3}\left(a_{1}\right)=100 \frac{(100-70)}{(100-0)} \%=30 \\
& u_{4}\left(a_{1}\right)=100 \frac{(100-81)}{(100-0)} \%=19 \\
& u_{5}\left(a_{1}\right)=100 \frac{(100-80)}{(100-0)} \%=20 \\
& u_{6}\left(a_{1}\right)=100 \frac{(100-85)}{(100-0)} \%=15
\end{aligned}
$$

5. Hitung nilai akhir masing-masing alternatif dan melakukan perangkingan

Berikutnya dilanjutkan dengan menghitung nilai masing-masing alternatif dengan cara melakukan perkalian nilai utility dengan bobot menggunakan rumus:

$$
u\left(a_{i}\right)=\sum_{i=1}^{m} N_{i} u_{i}\left(a_{i}\right)
$$

$\mathrm{A} 1=(0.18 * 10)+(0.16 * 14)+(0.17 * 30)+(0.18 * 19)+(0.16 * 20)+(0.17 * 15)=17.92$

$\mathrm{A} 2=(0.18 * 26)+(0.16 * 11)+(0.17 * 5)+(0.18 * 21)+(0.16 * 28)+(0.17 * 21)=18.70$

$\mathrm{A} 3=(0.18 * 6)+(0.16 * 4)+(0.17 * 25)+(0.18 * 8)+(0.16 * 27)+(0.17 * 15)=13.93$

A4 $=(0.18 * 12)+(0.16 * 16)+(0.17 * 19)+(0.18 * 22)+(0.16 * 16)+(0.17 * 29)=19.00$

$\mathrm{A} 5=\left(0.18^{*} 18\right)+\left(0.16^{*} 25\right)+(0.17 * 12)+(0.18 * 7)+\left(0.16^{*} 13\right)+(0.17 * 13)=14.60$

\subsection{Pengujian}

Teknik pengujian sitem dilakukan dengan cara menginput data pegawai, kemudian menginput data bobot penilaian untuk kriteria, menginput data bobot penilaian tiap-tiap pegawai, melakukan proses perhitungan dengan metode SMART pada sistem dan mencetak hasil perhitungan pada sistem.

1. Menu Utama

Gambar implementasi hasil dari menu utama yang telah diselesaikan dapat dilihat pada gambar 5.1 berikut ini.

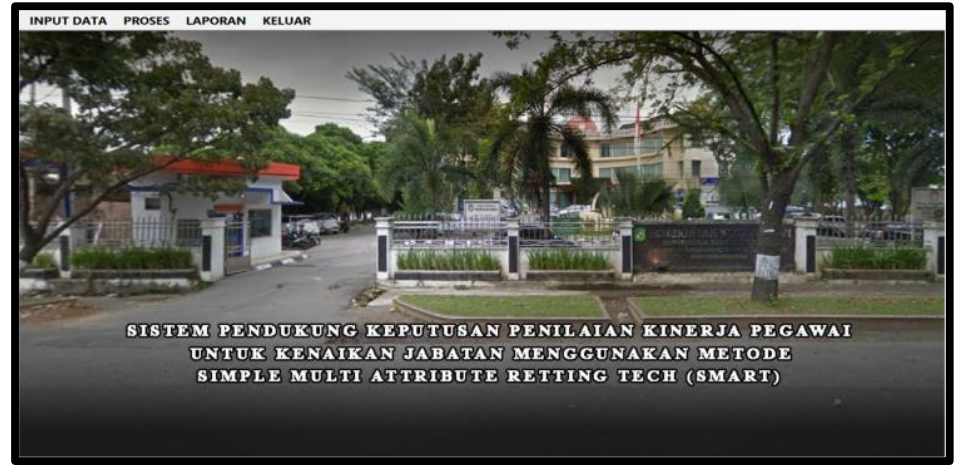

Gambar 5.1 Form Menu Utama 
2. Form data pegawai

Pengujian dilanjutkan dengan menginput data pegawai kedalam sistem seperti terlihat pada gambar 5.2 berikut ini.

3. Form data kriteria

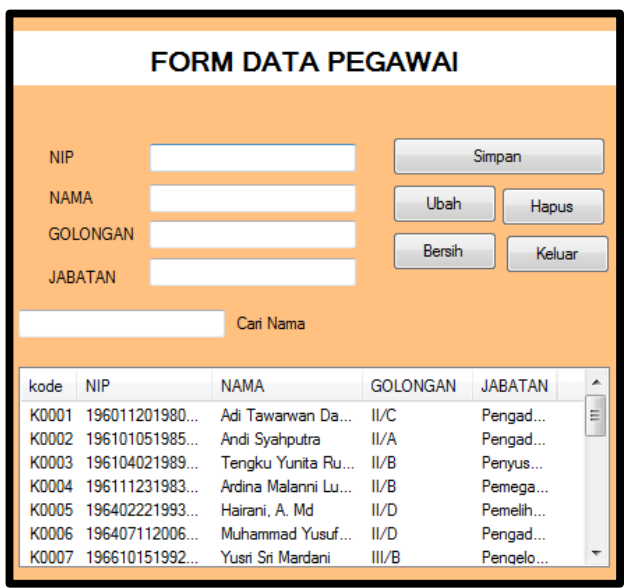

Gambar 5.2 Form Data Pegawai

Pengujian menginput data bobot kriteria pada alikasi dilakukan di form data bobot kriteria. Hasil penginputan data bobot dapat dilihat pada gambar 5.3 berikut ini.

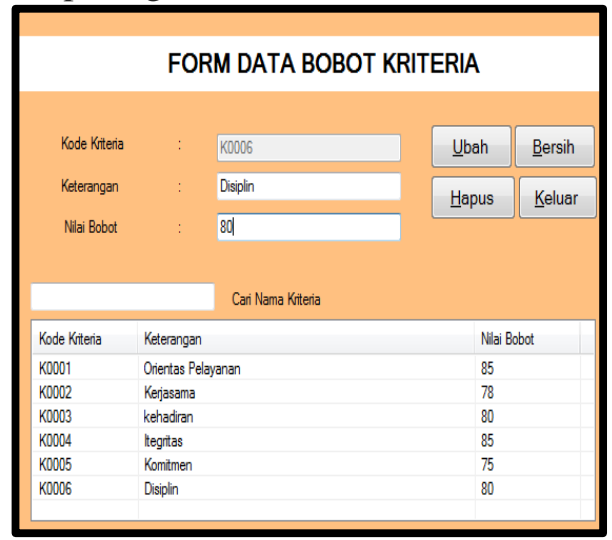

4. Form data penilaian

Gambar 5.3 Form Data Kriteria

Pengujian form data penilaian dilakukan dengan menginput data penilaian bagi masing-masing pegawai pada form penilaian pegawai. Proses pengujian dapat dilihat pada gambar 5.4 berikut ini.

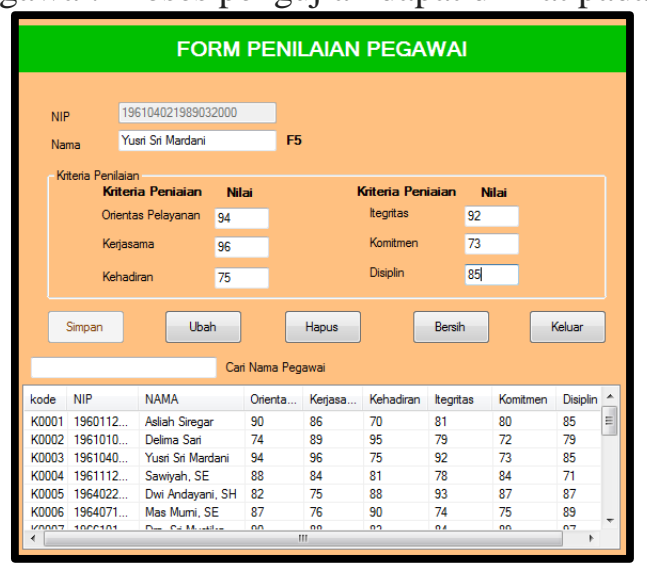

Gambar 5.4 Form Data Penilaian 
5. Form proses perhitungan

Setelah data penilaian pegawai selesai diinput, maka proses perhitungan dengan metode SMART dilakukan di form proses di dalam sistem. Hasil proses pengujian dapat dilihat pada gambar 5.5 berikut ini.

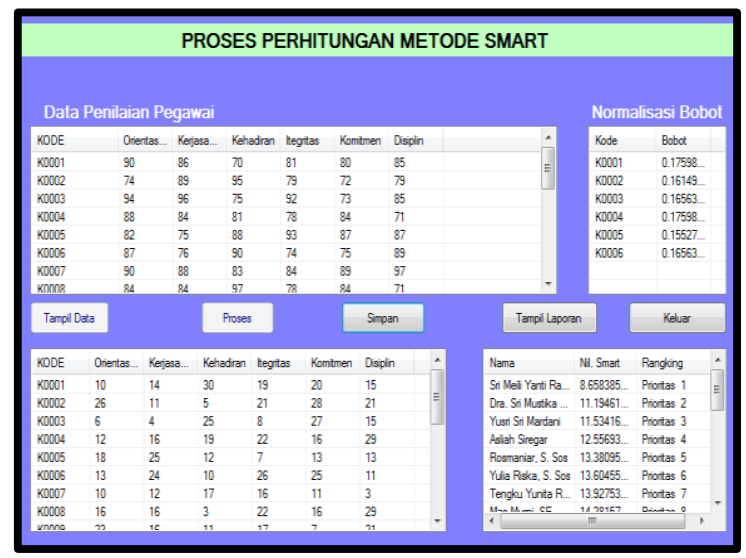

\section{Gambar 5.5 Form Proses Perhitungan}

6. Laporan hasil perhitungan

Gambar implementasi hasil dari menu utama yang telah diselesaikan dapat dilihat pada gambar 5.6 berikut ini.

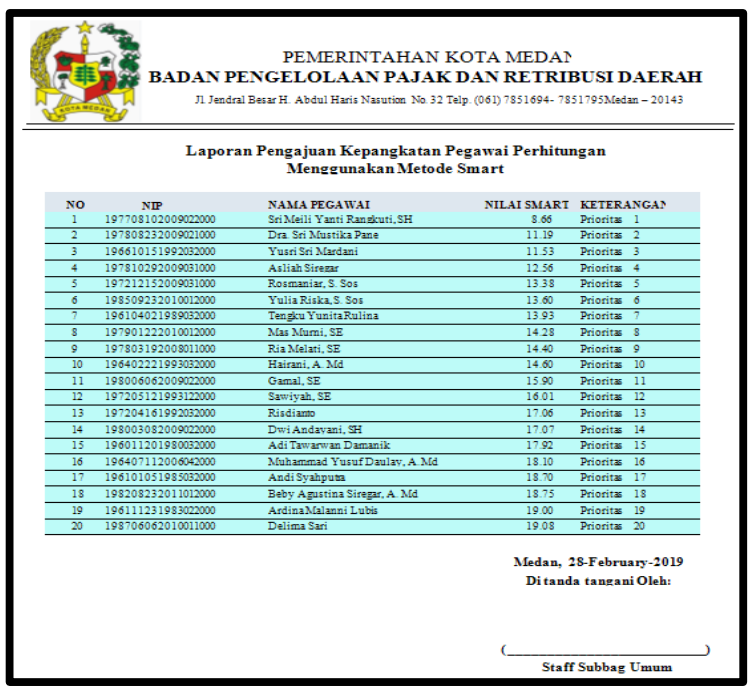

Gambar 5.6 Form Laporan Hasil Perhitungan

\section{Kesimpulan}

Berdasarkan hasil analisis dan pengujian dari sistem pendukung keputusan penilaian kinerja pegawai untuk kenaikan jabatan menggunakan metode Simple Multi Attribute Retting Tech (SMART) kepada pengguna maka mendapat kesimpulan sebagai berikut:

1. Menentukan penilaian kinerja pegawai untuk kenaikan pangkat dengan metode SMART dengan cara mengurutkan nilai terkecil dari hasil perhitungan dan menampilkan hasil dalam bentuk laporan yang dapat di cetak. 
2. Metode SMART berhasil diterapkan dalam sistem pendukung keputusan dengan menggunakan aplikasi visual studio 2008 dan database access 2010 untuk menyimpan data pegawai dan data hasil perhitungan.

3. Sistem pendukung keputusan berbasis desktop dirancangan dengan menerapkan metode SMART dan hasil perhitungannya dapat dicetak pada media kertas dan sistem yang telah diuji menghasilkan kinerja yang baik dengan nilai accuracy $95 \%$.

\section{DAFTAR PUSTAKA}

[1]. Eva Yulianti. (2015). Sistem pendukung keputusan pemilihan mobil Dengan metoda simple multy attribute rating (smart). Vol.17 No.1. Februari 2015 Jurnal Momentum ISSN : 1693-752X.

[2]. Yeni Purnamasari,Tacbir Hendro Pudjiantoro, Dian Nursantika. (2017). Sistem penilaian kinerja dosen teladan menggunakan metode simple multy attribute rating technique (SMART), Jurnal Teknologi Elektro, Universitas Mercu Buana ISSN : 2086-9479, Vol. 8 No.1 Januari 2017.

[3]. Tisa Magrisa, Kartina Diah Kusuma Wardhani dan Maksum Ro'is Adin Saf (2018).

Implementasi metode smart pada sistem pendukung Keputusan pemilihan kegiatan ekstrakurikuler untuk Siswa SMA Informatika Mulawarman : Jurnal Ilmiah Ilmu Komputer Vol. 13, No. 1 Februari 201849 e-ISSN 2597-4963 dan p-ISSN 1858-4853.

[4]. Suryanto, Muhammad Safrizal. (20015). Sistem Pendukung Keputusan Pemilihan Karyawan Teladan dengan Metode SMART (Simple Multi Attribute Rating Technique). Jurnal CoreIT, Vol.1, No.2, Desember 2015 Issn: 2460-738x.

[5]. Zulfi Azhar. (2018). Penentuan Penempatan Karyawan Baru Di Pdam Kisaran Dengan Metode Smart. Jurteksi (Jurnal Teknologi Dan Sistem Informasi) Issn 2407-1811 (Print) Vol. Iv No. 2, Jun 2018, Hlm. 179 - 184 Issn 2550-0201 (Online).

[6]. I Made Ari Santosa (2017). Perancangan Sistem Pendukung Keputusan Pemilihan Sekolah Paud Menggunakan Metode Smart, Konferensi Nasional Sistem \& Informatika 2017 Stmik Stikom Bali, 10 Agustus 2017.

[7]. Heliawaty Hamrul. (2015) Sistem Penunjang Keputusan Untuk Pemilihan Konsentrasi Di Fakultas Teknik Komputer Menggunakan Metode Smart - Jurnal Ilmiah D'computare Volume 5 Januari 2015

[8]. Trinanda Syahputra, Milva Yetri, Siwi Dwi Armaya, I. (2017). Sistem Pengambilan Keputusan Dalam Menentukan Kualitas Pemasukan Pangan Segar Metode Smart Jurteksi (Jurnal Teknologi Dan Sistem Informasi) Issn 2407-1811

[9]. Heliza Rahmania Hatta1,Budi Gunawan2,Dyna Marisa Khairina3 (2017). Pemilihan Pemain Terbaik Futsal Dengan Metode Simple Multi Attribute Rating

[10]. Tecnique Studi Kasus: Turnamen Futsal Di Samarinda, Jurnal Informatika Vol.11.No1, Jan 2017 